\title{
New distributional data of the protected butterfly Papilio alex- anor Esper, 1800 in north-western Italy and some ecological observations (Lepidoptera Papilionidae)
}

Luca Anselmo

Cottian Alps Protected Areas Management Authority - Via Fransuà Fontan 1, 10050 Salbertrand, Turin, Italy; e-mail: luca.anselmo@hotmail.it

\begin{abstract}
Data concerning a new population of Papilio alexanor Esper, 1800 (Lepidoptera Papilionidae) observed by the author in north-western Italy is here reported. In summer 2020, seventyfive caterpillars of this rare and emblematic species have been found in the upper Susa Valley (Cottian Alps) on Ptychotis saxifraga, at relatively high altitude. The analysis of the observations carried out on a random sample of host plants suggest similar ecology but delayed phenology, compared to that reported for other Italian populations.
\end{abstract}

KEY WORDS Conservation; Cottian Alps; Habitats Directive; phenology; Ptychotis saxifraga.

Received 26.11.2020; accepted 28.12.2020; published online 25.01.2021

\section{INTRODUCTION}

The swallowtail butterfly Papilio alexanor Esper, 1800 (lepidoptera Papilionidae) show a high fragmented geographical range, which extends from south-eastern France to Central Asia (Bollino \& Sala, 2004). In Europe, it is extremely localized, mainly in south-eastern France and Greece (Lafranchis et al., 2015). Until today, the confirmed presence in Italy was known in only few sites in the Ligurian and Italian Maritime Alps (Balletto et al., 2014; Genovesi et al., 2014; Bonelli et al., 2015). In the past, the species was also captured in the south of the peninsula, namely in Calabria and Sicily (Bollino \& Sala, 2004; Balletto et al., 2014). However, for these observations, a stable population is not confirmed and the few adults collected could refer to stray specimens coming from Balkans (Balletto et al., 2014; Bonelli et al., 2015).

In north-western Italy, the species is mostly found in calcareous, south-facing areas from around
500 to $1200 \mathrm{~m}$ of elevation, observed at maximum of $2100 \mathrm{~m}$ (Bonelli et al., 2015). In these habitats, this thermophilous species find its host plants, typical in steep and rocky slopes: mainly Ptychotis saxifraga (L.) Loret \& Barrandon, but also Trinia glauca (L.) Dumort (Nel \& Chauliac, 1983; Bollino $\&$ Sala, 2004). At lower elevations of Ligurian Alps, the species can feeds also on Opoponax chironium (L.) Koch (Reche 1978). Papilio alexanor is monovoltine and adults can be found from late March to late July, depending on locality (Bollino \& Sala 2004). Larval development lasts on average 22 days (Bonelli et al., 2015) and includes five stages (Bollino \& Sala, 2004; Bonelli et al., 2015; Baruzzi et al., 2016). Overwintering occurs with pupation and diapause can last up to three years (Nakamura \& Ae, 1977; Bollino \& Sala, 2004).

Papilio alexanor is listed in Annex IV of the Habitats Directive (92/43/CEE) and in Appendix II of the Bern Convention. Although this species shows a decline in part of its range, it is not believed 
to face major threats at the European and Mediterranean scale, therefore it is classified as LC (least concern) according to the IUCN threat categories (van Swaay et al., 2010, 2014). Conversely, in Italy it is considered EN (endangered) in the Red List of the Italian Butterflies, due to its small distribution range (Balletto et al., 2015) and the conservation status under Art. 17 of the Habitats Directive is unfavorable-inadequate, with worsening trend (Genovesi et al., 2014). The threats to this species are mainly due to climate change (Settele et al., 2008) and illegal collecting (Balletto \& Kundra, 1985; Balletto et al., 2015; Bonelli et al., 2015).

The present paper contributes to increase the distribution knowledge of $P$. alexanor, thanks to the research I conducted in Susa Valley (north-western Italy) in the last few years.

\section{MATERIAL AND METHODS}

The Susa Valley is located in the Cottian Alps, bordering France for a large part of its perimeter. This area has a surface of about $1200 \mathrm{~km}^{2}$, with broad elevation range from 300 to $3612 \mathrm{~m}$. Compared to the surrounding, this is a well-defined alpine sector from climatic point of view, having conditions of high continentality and xericity. The low values of annual and summer rainfall are mainly due to the opening to the west towards the French Alps and the prevailing westerly winds with mainly parallel direction to the valley (De Biaggi et al., 1990).

I systematically researched Papilio alexanor and its host plants in suitable habitats described by Bonelli et al. (2015), in the summers of 2018, 2019 and 2020. In 2020, I carried out a sampling in the new occurrence area, in order to obtain preliminary ecological information, noting the abundance of caterpillars on host plants and some respective features. No specimens were taken and a subsample of occupied plants were occasionally visited during the development period of the caterpillars, in order to collect phenological information. Statistical analysis were performed with RStudio (ver. 1.1.463).

\section{RESULTS}

On 28 July 2020 I found some caterpillars of
Papilio alexanor in the upper Susa Valley. The site is located in LQ19 10 x $10 \mathrm{~km}$ UTM grid cell, according with the data mapping method provided in Ruffo \& Stoch (2005). This is at about $80 \mathrm{~km}$ of linear distance from the closest site mapped in the Third National Report under Art. 17 of the Habitats Directive (Genovesi et al., 2014) (Fig. 1). On July 31 I carried out a more in-depth survey, scanning a random sample of potential hosts plants approachable in relative safety conditions $(n=112)$. On that occasion I was able to count a total of 75 caterpillars on Ptychotis saxifraga, on calcareous, landslide slopes with prevalent southern exposure (Fig. 2). The altitudinal range of the observations is between 1380 and $1480 \mathrm{~m}$ of elevation, but it is possible that the species occur also at a higher altitude. The maximum linear distance between two observations is about $1.6 \mathrm{~km}$ (Fig. 3).

The presence of caterpillars occurred in $27.3 \%$ of the inspected plants. The height of the occupied plants was significantly greater than the height of the unoccupied ones (Wilcoxon test: $\mathrm{W}=2008, \mathrm{p}$ $<0.01$ ) (Fig. 4). Analyzing the morphology of the caterpillars and comparing it with the description provided by Baruzzi et al. (2016), these were mostly at the beginning of L3 instar (Figs. 5, 6).

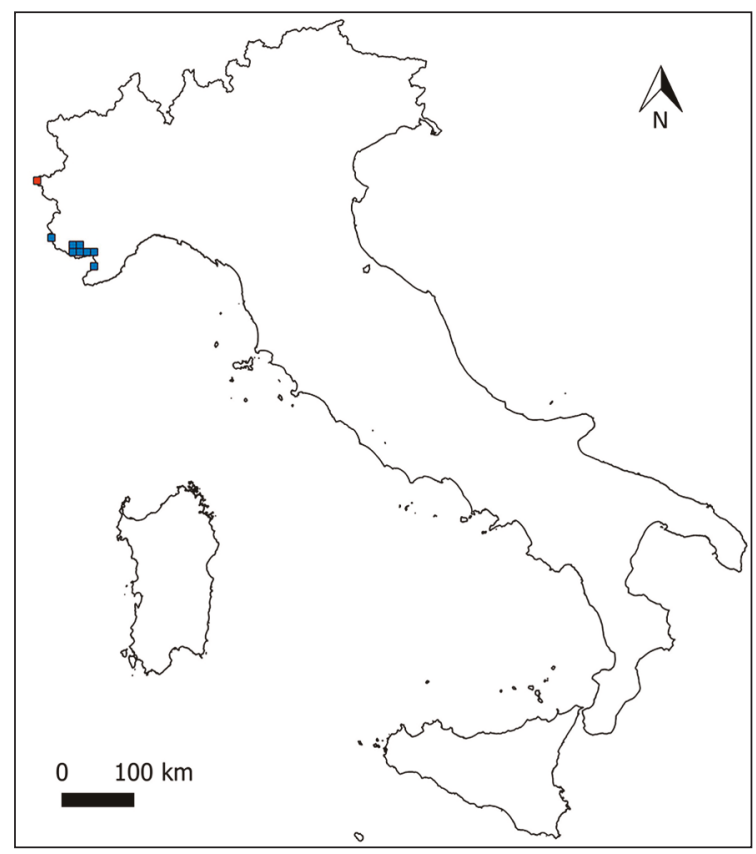

Figure 1. Updated distribution of Papilio alexanor in Italy: new data (red square) and data from Third National Report by Genovesi et al. (2014) (blue squares). 


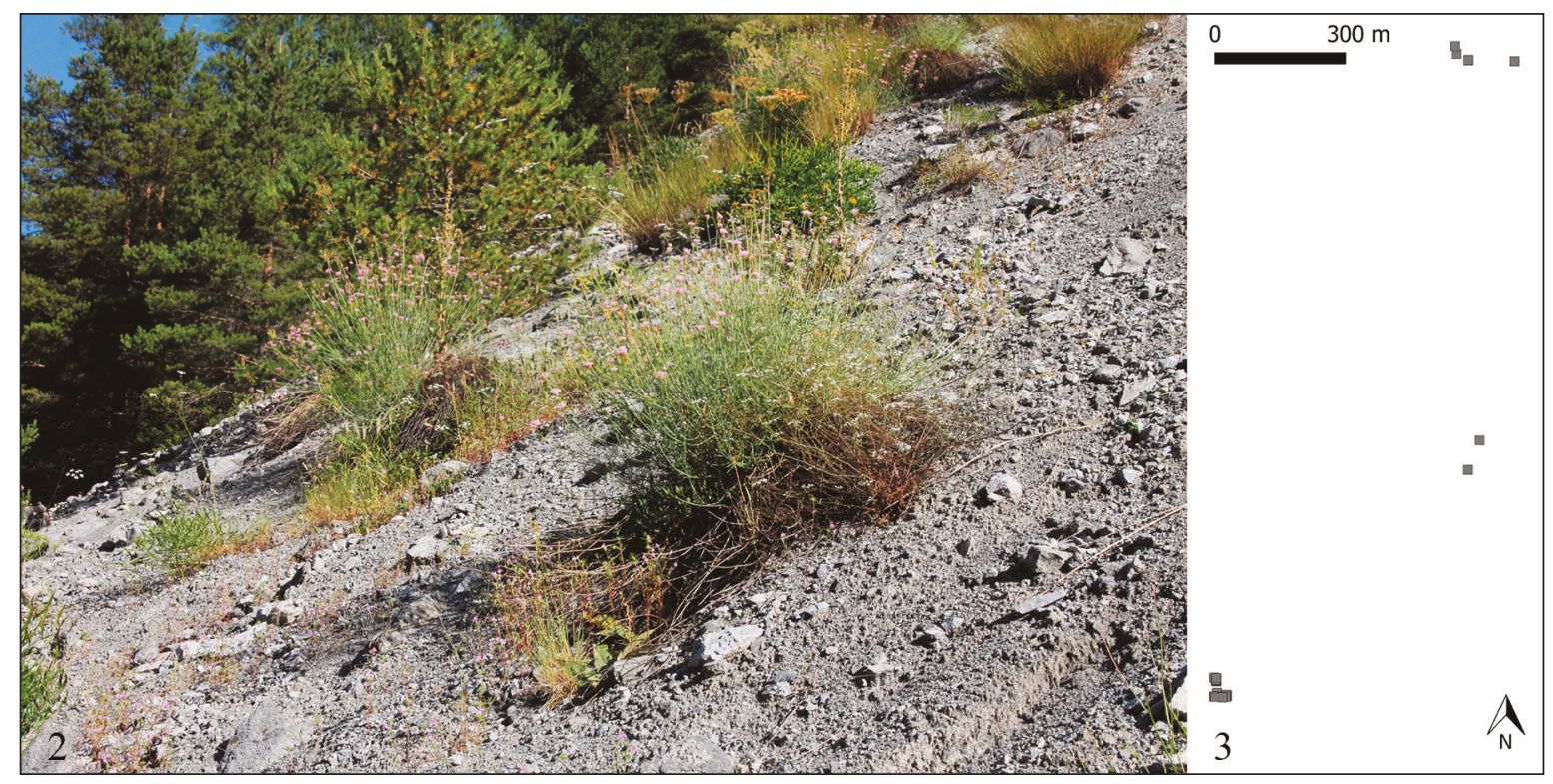

Figures 2, 3. Data collected on 31 July 2020: representative biotope (Fig. 2); spatial distribution of occurrences (Fig. 3).

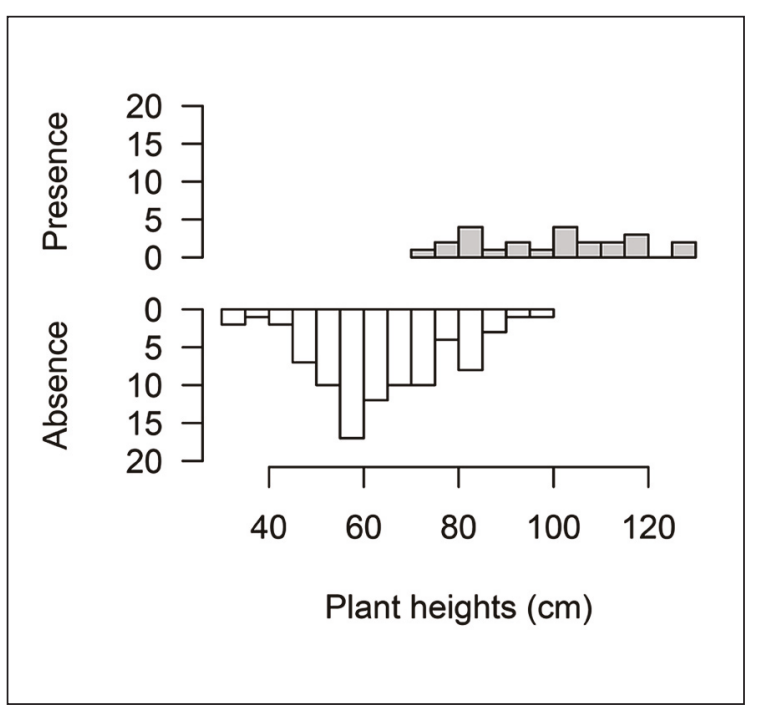

Figure 4. Comparison of the height frequencies of the inspected plants on the basis of presence/absence of caterpillars on 31 July 2020.

Their length seems to be shorter than that reported by Bonelli et al. (2015) and Baruzzi et al. (2016), who however refer to the subsp. radighierii Sala \& Bollino, 1991, which is larger in size than other populations (Bollino \& Sala, 2004). On subsequent visits, almost all individuals observed had reached at L4 on August 5 and L5 on August 13 (Figs. 7, 8).

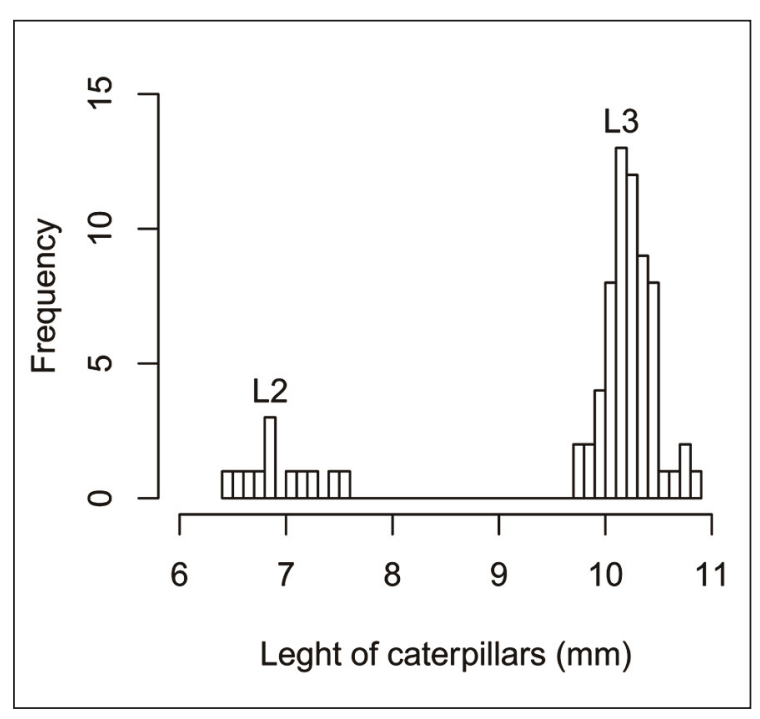

Figure 5. Comparison of the length measurements of the two stages of the caterpillars recorded on 31 July 2020 in the study area.

\section{DISCUSSION}

The reported observations of Papilio alexanor constitutes new distributional data for Italy. However, it should be noted that the possible occurrence of the species in the upper Susa Valley had been suggested by Sindaco et al. (2018), given the short distance to the records for Provence-Alpes-Côte 


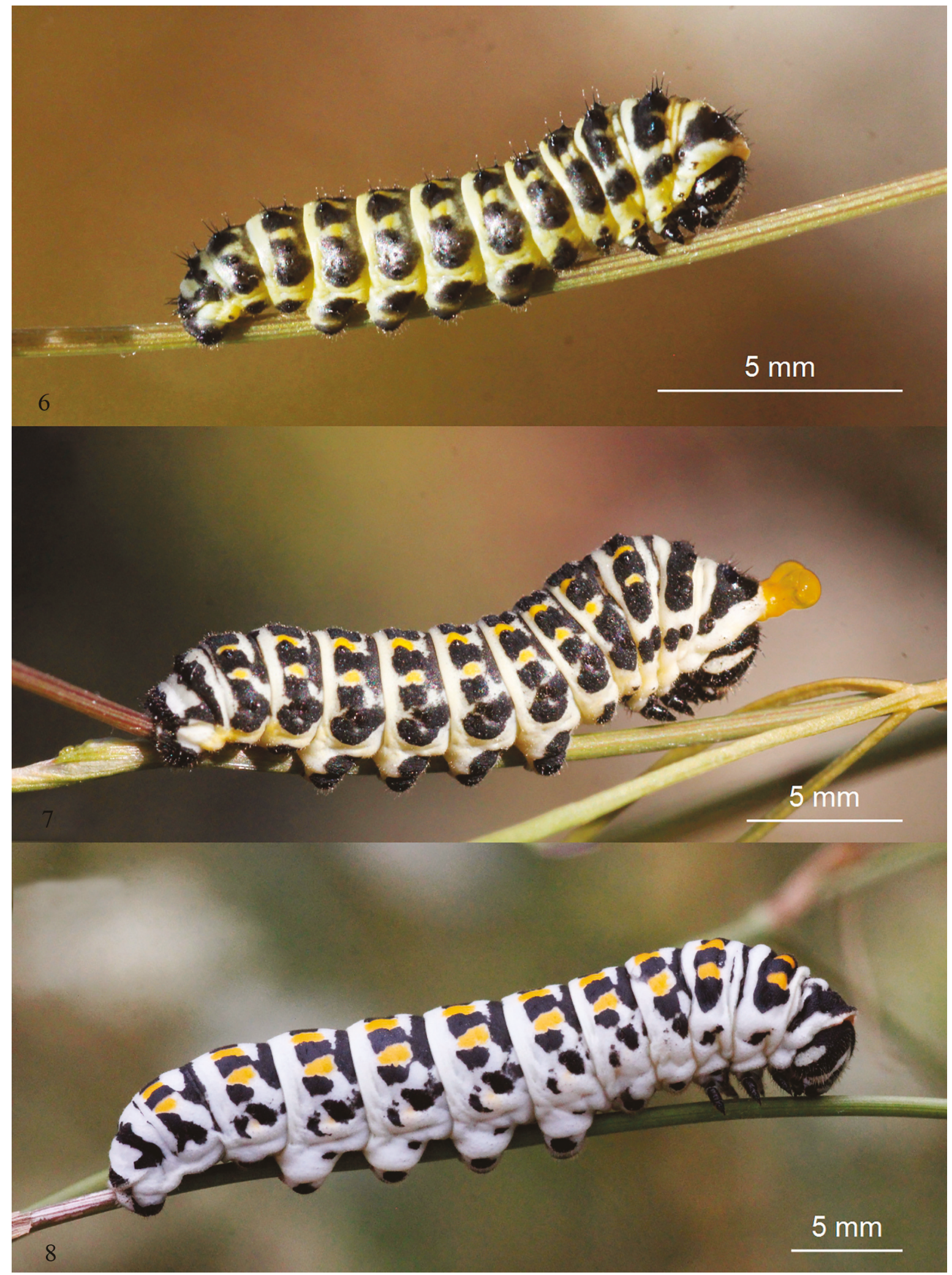

Figures 6-8. Larval development of Papilio alexanor: L3, 31 July 2020 (Fig. 6); L4 with partial everted osmeterium, 5 August 2020 (Fig. 7); L5, 13 August 2013 (Fig. 8). 
d'Azur (south-eastern France), reported today by Bence \& Richaud (2020). Previously, Sindaco et al. (2003) have mapped the species in the Susa Valley area, but referring to some caterpillars illegally introduced in the past (Hellmann \& Bertaccini, 2004; Hellmann \& Parenzan, 2010; Sindaco et al., 2018). It must be specified that these observations refer to another site in the valley (between Claviere and Cesana Torinese) and, in addition, the specimens introduced have been observed by some entomologists for only one season (E. Bertaccini, pers. comm.).

The new presence site could set the maximum altitude record for reproduction in Italy. Based on the collected data, the ecology of the species appears similar to that reported for Maritime Alps by Bonelli et al. (2015), in particular about the preference for taller plants for reproduction. However, phenology is more retarded, since the development of the caterpillars falls almost completely in August. This may be a reason why the species has not been sampled in the past: as indicated in Stoch \& Genovesi (2016) the monitoring of Italian populations related to Ptychotis saxifraga should be carried in July, which in this case would not certainly matches with the best period to spot the caterpillars. Furthermore, it is not excluded that the new data derive from a recent expansion of the species, given the great colonizing capacity to new, climatically suitable sites, as suggested by the observations of individuals far north from its actual range especially during the warmest summers (Bonelli et al., 2015). About this, the new area of occurrence can be considered of particular interest looking to climate changes, given the high vagility that characterizes this species (Balletto \& Kundra, 1985; Lafranchis et al., 2015) and the availability of host plants also in other parts of the valley and at higher altitude (pers. obs.).

For conservation purposes it will be necessary to carefully monitor and protect the area of occurrence, which fortunately falls within the territory covered by the Natura 2000 network. For this reason, precise geographical coordinates of the observations are not provided in this paper.

Finally, I would like to thank those who take care of the protection of this rare insect, citing the conclusion of the work of Bollino \& Sala (2004), which somehow stimulated and announced my discovery: "we are sure that Papilio alexanor is much more common and widespread there than supposed, and its political and geographical isolation is, after all, its best defence!".

\section{ACKNOWLEDGMENTS}

I want to thank E. Bertaccini (Roncadello di Forlì, Italy) and R. Sindaco (Torino, Italy) for their personal communications. I thank all my friends, my family and my colleagues who continue to support my passion for the biodiversity of the Susa Valley, a land of endless surprises. I especially thank Marta, who shared with me the joy in the first discovery of the beautiful caterpillars of this fascinating species.

\section{REFERENCES}

Balletto E. \& Kudrna O., 1985. Some aspects of the conservation of butterflies in Italy, with recommendations for a future strategy. Bollettino della Società Entomologica Italiana, 117: 39-59.

Balletto E., Cassulo L.A. \& Bonelli S., 2014. An annotated checklist of the Italian butterflies and skippers (Papilionoidea, Hesperioidea). Zootaxa, 3853 (1): 1114. https://doi.org/10.11646/zootaxa.3853.1.1

Balletto E., Bonelli S., Barbero F., Casacci L.P., Sbordoni V., Dapporto L., Scalercio S., Zilli A., Battistoni A., Teofili C. \& Rondinini C., 2015. Lista Rossa IUCN delle Farfalle Italiane - Ropaloceri. Comitato Italiano IUCN e Ministero dell'Ambiente e della Tutela del Territorio e del Mare, Roma, 45 pp.

Baruzzi A., Bendazzi I., Caimi C., Pezzi G. \& Sala G., 2016. Osservazioni sul Papilio alexanor radighierii Sala \& Bollino, 1991. Quaderno di Studi e Notizie di Storia Naturale della Romagna, 44: 127-162.

Bence S. \& Richaud S., 2020. Atlas des papillons de jour et zygènes de Provence-Alpes-Côte d'Azur. Le Naturographe, 550 pp.

Bollino M. \& Sala G., 2004. Synopsis of Papilio alexanor Esper, 1799 (An updated revue of its taxonomy and biology). Natura Edizioni Scientifiche, Bologna, $64 \mathrm{pp}$.

Bonelli S., Barbero F., Casacci L.P. \& Balletto E., 2015. Habitat preferences of Papilio alexanor Esper, [1800]: implications for habitat management in the Italian maritime Alps. In: Daugeron C., Deharveng L., Isaia M., Villemant C. \& Judson M., 2015. Mercantour/Alpi Marittime All Taxa Biodiversity Inventory. Zoosystema, 37: 169-177. https://doi.org/10. 5252/z2015n1a7 
De Biaggi E., Stoppa E. \& Scotta M., 1990. Proposta per una suddivisione del Piemonte in settori eco-geografici. Rivista Piemontese di Storia Naturale, 11: 3-40.

Genovesi P., Angelini P., Bianchi E., Dupré E., Ercole S., Giacanelli V., Ronchi F. \& Stoch F., 2014. Specie e habitat di interesse comunitario in Italia: distribuzione, stato di conservazione e trend. ISPRA, Serie Rapporti, 194/2014, 330 pp.

Hellmann F. \& Bertaccini E., 2004. I Macrolepidotteri della Valle di Susa - Italia Nord-occidentale (Alpi Cozie-Graie). Monografie XL. Museo Regionale di Scienze Naturali, Torino, 389 pp.

Hellmann F. \& Parenzan P., 2010. I Macrolepidotteri del Piemonte. Monografie XLVI. Museo Regionale di Scienze Naturali, Torino, 1057 pp.

Lafranchis T., Jutzeler D., Guillosson J. Y., Kan P., \& Kan B., 2015. La Vie des Papillons -Écologie, Biologie et Comportement des Rhopalocères de France. Diatheo: 137-138.

Nakamura I. \& AE S. A., 1977. Prolonged pupal diapause of Papilio alexanor: arid zone adaptation directed by larval host plant. Annals of the Entomological Society of America, 70: 481-484.

Nel J. \& Chauliac A., 1983. Une nouvelle sous-espèce de Papilio alexanor Esper isolée dans la Provence méridionale [Lep. Papilionidae]. Alexanor, 13: 1619.

Reche C., 1978. Opapanax chironium Koch, plante nourricière de Papilio alexanor Esper. Entomops, 45: $145-146$

Ruffo A. \& Stoch F., 2005. Checklist e distribuzione della fauna italiana. 10.000 specie terrestri e delle acque interne. Memorie de Museo di Verona, $2^{\mathrm{a}}$ serie, sez. Scienze della Vita, 16: CD-ROM.

Settele J., Kudrna O., Harpke A., Kühn I., van Swaay C.,
Verovnik R., Warren M., Wiemers M., Hanspach J., Hickler T., Kühn E., Van Halder I., Veling K., Vliegenthart A ., Wynhoff I. \& Schweiger O., 2008. Climatic Risk Atlas of European Butterflies. Pensoft, Sofia-Moscow, 712 pp.

Sindaco R., Mondino G.P., Selvaggi A., Ebone A. \& Della Beffa G., 2003. Guida al riconoscimento di Ambienti e Specie della Direttiva Habitat in Piemonte. Regione Piemonte: 146-147.

Sindaco R., Savoldelli P., Raviglione M., Boggio F., Bonifacino M. \& Cabella C., 2018. Le farfalle (Insecta: Lepidoptera) di interesse comunitario in Piemonte: stato attuale delle conoscenze. Rivista piemontese di Storia naturale, 39: 389-431.

Stoch F. \& Genovesi P., 2016. Manuali per il monitoraggio di specie e habitat di interesse comunitario (Direttiva 92/43/CEE) in Italia: specie animali. ISPRA, Serie Manuali e linee guida, 141/2016, 364 pp.

van Swaay, C., Wynhoff, I., Verovnik, R., Wiemers, M., López Munguira, M., Maes, D., Sasic, M., Verstrael, T., Warren, M. \& Settele, J., 2010. Papilio alexanor. The IUCN Red List of Threatened Species 2010: e.T174220A7031155. Downloaded on 26 November 2020.

van Swaay C., Wynhoff I., Wiemers M., Katbeh-Bader A., Power A., Benyamini D., Tzirkalli E., Balletto E., Monteiro E., Karaçetin E., Franeta F., Pe'er G., Welch H., Thompson K., Pamperis L., Dapporto L., Šašić M., López Munguira M., Micevski N., Dupont P., Garcia-Pereira P., Moulai R., Caruana R., Verovnik R., Bonelli S. \& Beshkov S., 2014. Papilio alexanor. The IUCN Red List of Threatened Species 2014: e.T174220A53719934. Downloaded on 09 November 2020. 